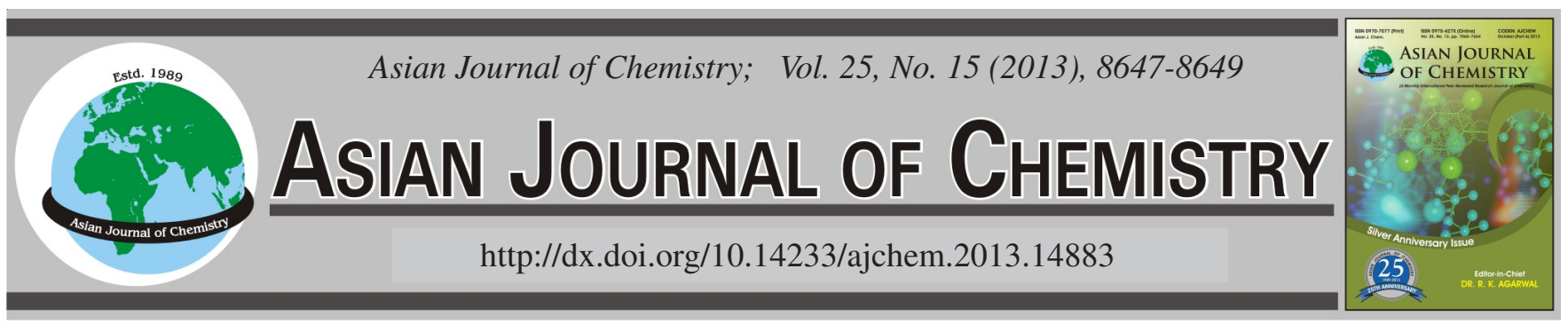

\title{
Removal of Chemical Nitrogen and Phosphorus of Micro-Polluted Water with Modified Zeolite Subsurface Wetland
}

\author{
HAO WANG ${ }^{1, *}$ and XUEJIN $\mathrm{LI}^{2}$
}

\begin{abstract}
${ }^{1}$ College of Civil and Architecture Engineering, Hebei United University, Tangshan, P.R. China
\end{abstract}
${ }^{2}$ Department of Foreign Languages, Tangshan College, Tangshan, P.R. China

*Corresponding author: E-mail: wanghao1689@gmail.com

(Received: 27 November 2012;

Accepted: 26 August 2013)

AJC-14017

\begin{abstract}
As the main matrix of subsurface wetland, the modified zeolite was applied to the treatment of micro-polluted water. The wetlands removal effect on the main pollutant in micro-polluted water was measured when the intermittent influent was adopted and the hydraulic loading was controlled to $0.278 \mathrm{~m}^{3} /\left(\mathrm{m}^{2} \mathrm{~d}\right)$ and $0.139 \mathrm{~m}^{3} /\left(\mathrm{m}^{2} \mathrm{~d}\right)$ and $0.093 \mathrm{~m}^{3} /\left(\mathrm{m}^{2} \mathrm{~d}\right)$. The results showed that the modified zeolite's removal rate on ammonia nitrogen, total nitrogen and total phosphorus were 86.7, 91.4 and $86.9 \%$, respectively, which showed that the best operating hydraulic loading was $0.093 \mathrm{~m}^{3} /\left(\mathrm{m}^{2} \mathrm{~d}\right)$. Furthermore, the subsurface wetland manifested increased removal effect on the pollutant with the decrease of hydraulic load.
\end{abstract}

Key Words: Modified zeolite, Micro-polluted water, Hydraulic loading rates, Removal rates.

\section{INTRODUCTION}

Constructed wetlands were considered as low-cost and ecological alternatives to conventional methods of wastewater treatment. Several types of wetlands could be employed to treat a variety of wastewater with success ${ }^{1-4}$. Constructed wetlands (CWs) for wastewater treatment have been extensively applied in many fields, including municipal wastewater, ground surface polluted water, farm dairy wastewater, oilfield drainage and eutrophic aquaculture wastewater ${ }^{5-9}$. Secondary effluent of wastewater treatment plants is further treated exiguously ${ }^{10}$. In most instances, the effluent is direct discharge to rivers and it will bring about river pollutions marginally. Thus, the secondary effluent of wastewater treatment plants is necessary to be treated to reduce any possible impacts on rivers ${ }^{6,11}$. This study focuses on using modified zeolite subsurface flow constructed wetlands for treating mico-polluted water on the variations of chemical pollutant concentration with the hydraulic loading rates.

\section{EXPERIMENTAL}

Experimental System: The experiment took place in a laboratory with a controlled environment in Tangshan of P.R. China. The vertical subsurface constructed wetland system was constructed, the main parts of the filled were four layers, substrate filter (from bottom): $10 \mathrm{~cm}$ gravel (particle size 15-25 $\mathrm{mm}$ ); $20 \mathrm{~cm}$ modified zeolite (particle size 6-10 $\mathrm{mm}$ ); $15 \mathrm{~cm}$ lytag (particle size 3-5 mm); $5 \mathrm{~cm}$ soil (with 10 mesh sieve mixed soil). Reeds and cattails were planted on soil layer. The wetland equipment was made of plexiglass, a single wetland specification for length $\times$ width $\times$ height $=60 \mathrm{~cm} \times 50 \mathrm{~cm} \times$ $60 \mathrm{~cm}$.

Influent quality: The raw wastewater, secondary effluent of wastewater treatment plants, was collected from wastewater treatment plant in Tangshan. The composition of the influent used in all experiments is shown in Table-1.

\begin{tabular}{lcc}
\multicolumn{3}{c}{ TABLE-1 } \\
\multicolumn{3}{c}{ CHARACTERISTICS OF THE WASTEWATER } \\
\multicolumn{2}{c}{ SAMPLE USED IN THE EXPERIMENTS } \\
\hline \multicolumn{1}{c}{ Parameter } & Unit & Concentration \\
\hline $\mathrm{pH}$ & - & $6.5-8.0$ \\
Ammonia nitrogen $\left(\mathrm{NH}_{3}-\mathrm{N}\right)$ & $\mathrm{mg} \mathrm{L}^{-1}$ & $24.5-32.7$ \\
Total nitrogen (TN) & $\mathrm{mg} \mathrm{L}^{-1}$ & $37.7-45.1$ \\
Total phosphorus (TP) & $\mathrm{mg} \mathrm{L}^{-1}$ & $4.5-5.0$ \\
\hline
\end{tabular}

Process of zeolite modification: Firstly, constructed wetland was washed 2 times by tap water, in order to reduce the experiment error the background value of matrix brings in, controlling the water level to the zeolite upper and that is the layer of zeolite contact with the soil. Secondly, it was injected with $\mathrm{NaCl}$ solution of $0.5 \mathrm{~mol} / \mathrm{L}$ and the time of soak was $2 \mathrm{~h}$. Thirdly, two days later, emptying the water, then the tap water is added into the wetland, while the $\mathrm{KMnO}_{4}$ solution of $0.5 \%$ was added into it, then soaking. Fourthly, evacuating 
the water, then pour the prepared wastewater into the wetland systems. At last, the system started.

\section{RESULTS AND DISCUSSION}

Ammonia nitrogen removal: As is shown in Fig. 1, in the pilot phase, vertical-modified zeolite wetlands of $\mathrm{NH}_{3}-\mathrm{N}$ in the sewage removal rate, when the hydraulic loading 0.278 $\mathrm{m} / \mathrm{d}$, the effluent concentration range is maintained at 1.42$3.59 \mathrm{mg} / \mathrm{L}$, the removal rate also remained at a lower level, the range of $61.8-84.8 \%$. With the gradual decrease of the hydraulic loading of the system $\mathrm{NH}_{3}-\mathrm{N}$ removal rate increased slightly, when the hydraulic loading $0.093 \mathrm{~m} / \mathrm{d}$, the effluent concentration range remained at $1.28-3.69 \mathrm{mg} / \mathrm{L}$, while the removal efficiency range from 64.4 to $86.7 \%$.

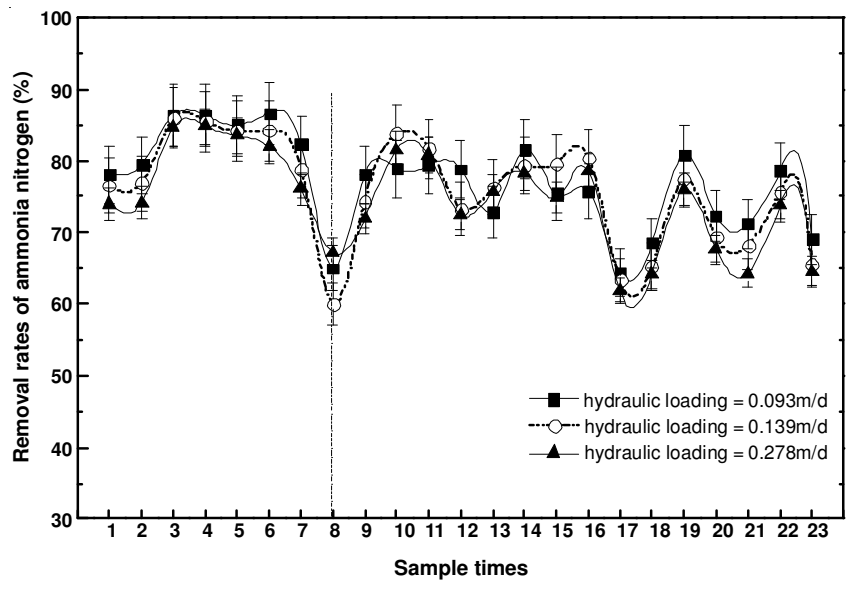

Fig. 1. Removal effect on ammonia nitrogen in vertical modified zeolite wetland under various hydraulic loading

Total nitrogen removal: As is shown in Fig. 2, in the early stages of the test, the vertical - modified zeolite wetland of sewage a total nitrogen removal effect is relatively stable and the removal rate is higher and as the prolonged operation time, the system of the sewage in the total nitrogen removal rate volatility to increase, to the latter part of the pilot phase, the system of sewage removal rate of total nitrogen value declined slightly. When the hydraulic loading $0.278 \mathrm{~m} / \mathrm{d}$, the scope of the effluent concentration was maintained at 1.86$7.25 \mathrm{mg} / \mathrm{L}$, the removal rate range is maintained at 62.0 to $89.8 \%$. With the gradual decrease of the hydraulic loading, vertical increased slightly modified zeolite wetland system for total nitrogen. When the hydraulic loading was $0.093 \mathrm{~m} / \mathrm{d}$, the scope of the effluent concentration was maintained at 1.65 $4.47 \mathrm{mg} / \mathrm{L}$, the removal rate range was from 78.1-91.4\%.

Total phosphorus removal: As is shown in Fig. 3, the vertical modified zeolite wetland system of total phosphorus removal was poor, especially in the end of the pilot phase, when the temperature has dropped, the removal efficiency of the system of total phosphorus sharp decline and volatile, this vertical modified zeolite wetland system insulation effect is less affected by temperature. Hydraulic loading of the impact of this system is more obvious that with the gradual decrease of the hydraulic loading, vertical modified zeolite wetland system total phosphorus removal increased slightly. When the hydraulic loading $0.278 \mathrm{~m} / \mathrm{d}$, the scope of the effluent concentration was maintained at $0.23-0.88 \mathrm{mg} / \mathrm{L}$, the removal rate

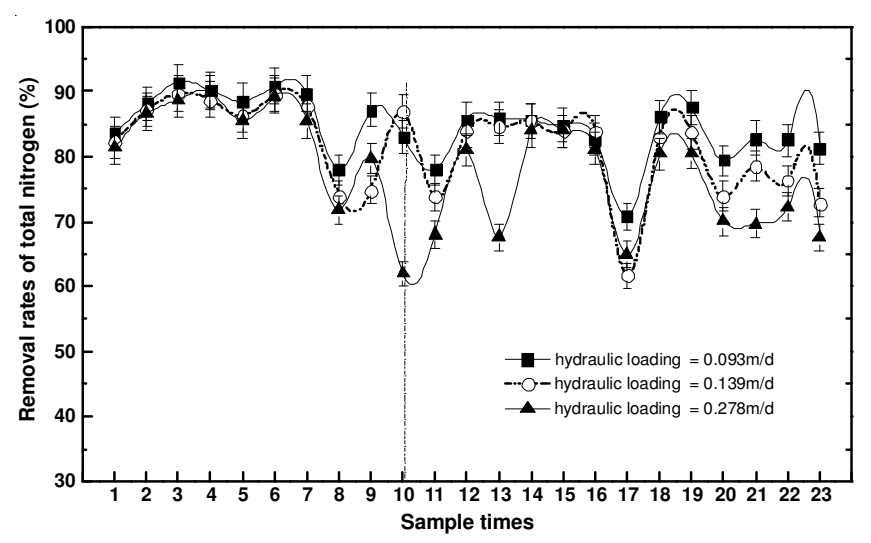

Fig. 2. Removal effect on total nitrogen in vertical modified zeolite wetland under various hydraulic loading

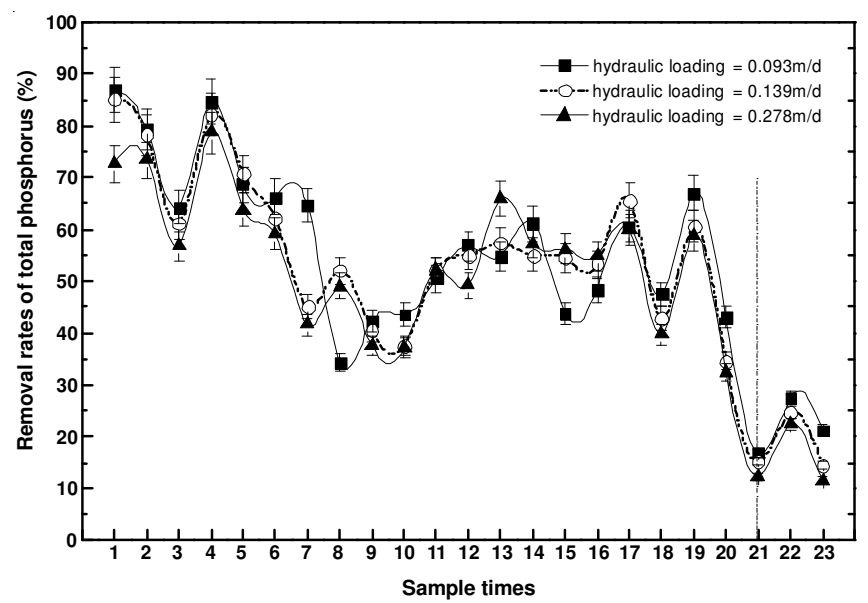

Fig. 3. Removal effect on total phosphorus in vertical modified zeolite wetland under various hydraulic loading

compared with $11.5-78.7 \%$. When the hydraulic loading was $0.093 \mathrm{~m} / \mathrm{d}$, the scope of the effluent concentration was maintained at $0.16-0.83 \mathrm{mg} / \mathrm{L}$, the removal rate range was from 16.7 to $86.9 \%$.

In the above experiments, the main analysis on the impact of hydraulic loading was each pollutant removal effect. First, determine $0.093 \mathrm{~m}^{3} /\left(\mathrm{m}^{2} \mathrm{~d}\right)$ for the best run hydraulic loading at the beginning of the trial of the running load, vertical modified zeolite obvious effect of the removal of $\mathrm{NH}_{3}-\mathrm{N}$, the removal rate was maintained at 87.3-92.9\%; vertical modified zeolite wetlands maintained at more than $67.5 \%$ for total nitrogen; while wet demonstration showed the trend of the first high to low total phosphorus removal effect.

\section{Conclusion}

The trial analyzed the impact of hydraulic loading of each pollutant removal effect in the best run hydraulic load conditions, the modified zeolite undercurrent wetlands sewage $\mathrm{NH}_{3}$ $\mathrm{N}$, the highest removal efficiency of total nitrogen and total phosphorus were $86.7,91.4$ and $86.9 \%$ of the tests showed that the modified undercurrent wet manifested gradually decreases as the hydraulic load, the nature of each pollutant removal rate gradually improve. Moreover, the nitrogen removals in the wetland maintained high removal efficiency while removal of total phosphorus from the first high to low trend. 


\section{ACKNOWLEDGEMENTS}

The financial support of this research by Hebei Construction Science and Technology Research Program (2013-143) in P.R. China and Scientific Research Foundation for Doctor of HEUU (35394701) are gratefully acknowledged.

\section{REFERENCES}

1. Anamika, Asian J. Chem., 20, 4659 (2008).

2. N. Mehrdadi, A. Rahmani, A.A. Azimi and A. Torabian, Asian J. Chem., 21, 5245 (2009).

3. H. Wang and L. Zhang, Asian J. Chem., 24, 5299 (2012).
4. C.C. Tanner, J.P.S Sukias and P.U. Martin, Water Res., 32, 3046 (2007).

5. N. Korboulewsky, R.Y. Wang and V. Baldy, Bioresour. Technol., 105, 9 (2012).

6. G.D. Ji, T.H. Sun, Q.X. Zhou, X. Sui, S.J. Chang and P.J. Li, Ecol. Eng., 18, 459 (2002).

7. Y.F. Lin, S.R. Jing, D.Y. Lee and T.W. Wang, Aquaculture, 209, 169 (2002).

8. H. Wang, X.W. He, T.Q. Liu and C.H. Zhang, Fresen. Environ. Bull., 20, 2890 (2011).

9. F. Rivera, A. Warren and C.R. Curds, Water Sci. Technol., 35, 271 (1997).

10. C.J. Richardson and S.S. Qian, Environ. Sci. Technol., 33, 1545 (1999).

11. C.C Tanner, J.P.S. Sukias and M.P. Upsdell, Water Res., 32, 3046 (2007). 